\title{
A Comparison of the Financial Characteristics of NAFTA and Latin American Manufacturing Firms
}

\section{Gulser Meric}

Professor of Finance, Rohrer College of Business, Rowan University

Glassboro, New Jersey 08028 | meric@ @rowan.edu

\section{Cengiz Haksever}

Professor of Decision Sciences, College of Business Administration, Rider University

Lawrenceville, New Jersey 08648 | haksever@ rider.edu

\section{J. Drew Procaccino}

Associate Professor of Information Systems, College of Business Administration

Rider University, Lawrenceville, New Jersey 08648 | procaccinod@ rider.edu

\section{Ilhan Meric}

Professor of Finance, College of Business Administration, Rider University

Lawrenceville, New Jersey 08648 | meric@ rider.edu

Volume 6 No 2 (2016) ｜ＩSSN 2158-8708 (online) ｜ＤOI 10.5195/emaj.2016.102 | http://emaj.pitt.edu |

\begin{abstract}
Comparing the financial characteristics of firms in different countries and different regions has been a popular research topic in finance. However, NAFTA and Latin American manufacturing firms have never been compared. In this paper, we undertake such a study with the MANOVA (Multivariate Analysis of Variance) method with data drawn from the Research Insight/Global Vintage database in October 2015. Our findings indicate that NAFTA manufacturing firms have less liquidity risk, but more financial risk, compared with Latin American manufacturing firms. NAFTA manufacturing firms have significantly higher returns on equity due to achieving higher returns on assets and using more financial leverage. Latin American manufacturing firms have more efficient inventory management. However, NAFTA manufacturing firms have more efficient accounts receivable management and total assets management.
\end{abstract}

Keywords: Financial Ratios, NAFTA manufacturing firms, Latin American manufacturing firms, MANOVA (Multivariate Analysis of Variance)

\section{$(\mathrm{cc}) \mathrm{EY}$}

New articles in this journal are licensed under a Creative Commons Attribution 3.0 United States License.

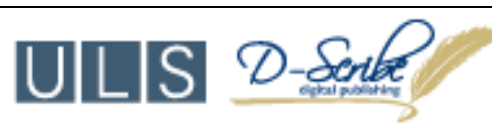

This journal is published by the University Library System of the University of Pittsburgh as part

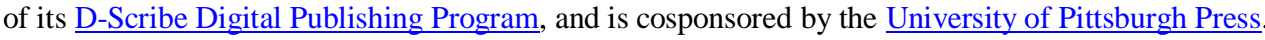




\section{A Comparison of the Financial Characteristics of NAFTA and Latin American Manufacturing Firms}

\section{Gulser Meric \\ Cengiz Haksever \\ J. Drew Procaccino \\ Ilhan Meric}

\section{Introduction}

Comparing the financial characteristics of different groups of firms has long been a popular methodology in finance. Altman (1968), Beaver (1968), Deakin (1972), Moyer (1977), Edmister (1972), and Dambolena and Khoury (1980) predict bankruptcy by comparing the financial characteristics of bankrupt and non-bankrupt firms. Stevens (1973), Belkaoui (1978), Rege (1984), and Meric at al. (1991) identify the financial characteristics of firms that have been corporate takeover targets by comparing them with firms that have not been corporate takeover targets. Hutchinson at al. (1988) and Meric and Meric (1992) identify the financial characteristics of firms which achieve stock market quotation by comparing them with firms that do not have stock market quotation. Meric at al. (2000) compare the financial characteristics of Japanese kieretsu-affiliated and independent firms to identify the financial characteristics of kieretsu-affiliated firms.

A number of studies compare the financial characteristics of firms in different countries. Kester (1986) and Wald (1999) compare the capital and ownership structures of firms in different countries and they find significant differences. Meric and Meric (1989 and 1994) compare the financial characteristics of U.S. and Japanese manufacturing firms and they find significant differences. In this study, we compare the financial characteristics of NAFTA and Latin American manufacturing firms.

\section{NAFTA and Latin American Economies}

In this section, we present an overview of the economies of the three NAFTA member countries and seven Latin America countries included in this study through various economic indicators. Table 1 includes population (based on 2015 estimates), population growth rate (based on 2015 estimates), labor force (based on 2014 estimates), and labor force as a percentage of population. We have also included a corresponding world rank for each of these indicators.

\section{Population}

The U.S. had the largest population among the NAFTA countries at $321.4 \mathrm{M}$ (fourth largest in the world) and Canada had the lowest at $35.1 \mathrm{M}$ (35 $5^{\text {th }}$ largest). Among the Latin American countries, Brazil had the highest population at 204.3M (sixth largest in the world) and Costa Rica had the smallest at $4.8 \mathrm{M}\left(124^{\text {th }}\right.$ largest $)$.

\section{Population Growth Rate}

Mexico had the highest population growth rate among the NAFTA countries at $1.2 \%\left(102^{\text {nd }}\right.$ highest in the world) and Canada was the lowest at $0.8 \%\left(146^{\text {th }}\right.$ highest). Among the Latin American countries, Venezuela had the highest at $1.4 \%\left(85^{\text {th }}\right.$ highest in the world), while Brazil had the lowest at $0.8 \%\left(142^{\text {nd }}\right.$ highest).

Table 1: Population, Growth Rate and Labor Force by Country

\begin{tabular}{|c|c|c|c|c|c|}
\hline & $\begin{array}{c}\text { Countr } \\
\mathbf{y}\end{array}$ & $\begin{array}{l}\text { Populati } \\
\text { on }^{1} \\
\text { [in } \\
\text { millions] } \\
\text { (world } \\
\text { rank) }\end{array}$ & $\begin{array}{c}\text { Populati } \\
\text { on }^{2} \\
\text { Growth } \\
\text { Rate } \\
\text { (world } \\
\text { rank) }\end{array}$ & $\begin{array}{c}\text { Labor } \\
\text { Force }^{3} \\
\text { [in } \\
\text { million } \\
\text { s] } \\
\text { (world } \\
\text { rank) }\end{array}$ & $\begin{array}{c}\text { Labor } \\
\text { Force } \\
\text { as } \\
\text { Percenta } \\
\text { ge } \\
\text { of } \\
\text { Populati } \\
\text { on }\end{array}$ \\
\hline \multirow{3}{*}{$\sum_{\frac{\pi}{2}}^{\frac{\pi}{2}}$} & Canada & $\begin{array}{l}35.1 \\
(39)\end{array}$ & $\begin{array}{l}0.8 \% \\
(146)\end{array}$ & $\begin{array}{l}19.2 \\
(32)\end{array}$ & $54.7 \%$ \\
\hline & Mexico & $\begin{array}{c}121.7 \\
(12)\end{array}$ & $\begin{array}{l}1.2 \% \\
(102) \\
\end{array}$ & $\begin{array}{l}52.9 \\
(13) \\
\end{array}$ & $43.5 \%$ \\
\hline & $\begin{array}{c}\text { United } \\
\text { State } \\
\mathrm{s}\end{array}$ & $\begin{array}{c}321.4 \\
(4)\end{array}$ & $\begin{array}{l}0.8 \% \\
(141)\end{array}$ & $\begin{array}{c}156.0 \\
(4)\end{array}$ & $48.5 \%$ \\
\hline \multirow{7}{*}{ 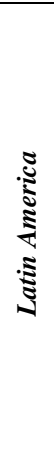 } & $\begin{array}{c}\text { Argenti } \\
\text { na }\end{array}$ & $\begin{array}{l}43.4 \\
(33)\end{array}$ & $\begin{array}{l}0.9 \% \\
(124)\end{array}$ & $\begin{array}{l}17.3 \\
(36)\end{array}$ & $39.9 \%$ \\
\hline & Brazil & $\begin{array}{c}204.3 \\
(6)\end{array}$ & $\begin{array}{l}0.8 \% \\
(142)\end{array}$ & $\begin{array}{c}110.9 \\
(6)\end{array}$ & $54.3 \%$ \\
\hline & Chile & $\begin{array}{l}17.5 \\
(64)\end{array}$ & $\begin{array}{l}0.8 \% \\
(137)\end{array}$ & $\begin{array}{c}8.5 \\
(58)\end{array}$ & $48.6 \%$ \\
\hline & $\begin{array}{c}\text { Columb } \\
\text { ia }\end{array}$ & $\begin{array}{l}46.7 \\
(30)\end{array}$ & $\begin{array}{l}1.0 \% \\
(115)\end{array}$ & $\begin{array}{l}23.7 \\
(28)\end{array}$ & $50.6 \%$ \\
\hline & $\begin{array}{l}\text { Costa } \\
\text { Rica }\end{array}$ & $\begin{array}{c}4.8 \\
(124)\end{array}$ & $\begin{array}{l}1.2 \% \\
(97)\end{array}$ & $\begin{array}{c}2.3 \\
(119)\end{array}$ & $46.9 \%$ \\
\hline & Peru & $\begin{array}{l}30.4 \\
(44)\end{array}$ & $\begin{array}{l}1.0 \% \\
(120)\end{array}$ & $\begin{array}{l}16.6 \\
(38)\end{array}$ & $54.4 \%$ \\
\hline & $\begin{array}{c}\text { Venezu } \\
\text { ela }\end{array}$ & $\begin{array}{l}29.3 \\
(45)\end{array}$ & $\begin{array}{l}1.4 \% \\
(85)\end{array}$ & $\begin{array}{l}14.3 \\
(40)\end{array}$ & $49.0 \%$ \\
\hline
\end{tabular}

Resources:

1 https://www.cia.gov/library/publications/resources/theworld-factbook/rankorder/2119rank.html

2 https://www.cia.gov/library/publications/resources/theworld-factbook/rankorder/2002rank.html

3 https://www.cia.gov/library/publications/resources/theworld-factbook/rankorder/2095rank.html

\section{Labor force}

The U.S. had the largest labor force among the NAFTA countries at $156.0 \mathrm{M}$ (fourth largest in the world) and Canada had the lowest at $19.2 \mathrm{M}$ ( $32^{\text {nd }}$ largest). Among the Latin American countries, Brazil had the highest labor force at $110.9 \mathrm{M}$ (sixth highest in the world) and Costa Rica had the smallest at $2.3 \mathrm{M}$ (119 ${ }^{\text {th }}$ highest). 
Table 2 includes total Gross Domestic Product (GDP) (2014 estimates, valued at prevailing U.S. purchase prices), annual GDP real growth rate (2014 estimates, adjusted for inflation), and annual GDP per capita (2014 estimates, valued at prevailing U.S. purchase prices). We have also included a corresponding world rank for each of these indicators.

Table 2: GDP Total, Growth Rate and Per Capita by Country

\begin{tabular}{|c|c|c|c|c|}
\hline & Country & $\begin{array}{c}\text { GDP Total } \\
\text { [in billions } \\
\text { US\$] } \\
\text { (world } \\
\text { rank) }\end{array}$ & $\begin{array}{c}\text { Annual } \\
\text { GDP } \\
\text { Real } \\
\text { Growth } \\
\text { Rate }^{2} \\
\text { (world rank) }\end{array}$ & $\begin{array}{c}\text { Annual } \\
\text { GDP } \\
\text { Per } \\
\text { Capita }^{3} \\
\text { [in US\$] } \\
\text { (world } \\
\text { rank) }\end{array}$ \\
\hline \multirow{3}{*}{$\frac{\pi}{2}$} & Canada & $\begin{array}{c}1,579.0 \\
(16)\end{array}$ & $\begin{array}{c}+2.3 \% \\
137\end{array}$ & $\begin{array}{c}44,500 \\
(29)\end{array}$ \\
\hline & Mexico & $\begin{array}{c}2,143.0 \\
(12)\end{array}$ & $\begin{array}{c}+2.4 \% \\
134\end{array}$ & $\begin{array}{c}17,900 \\
(92)\end{array}$ \\
\hline & $\begin{array}{l}\text { United } \\
\text { States }\end{array}$ & $\begin{array}{c}17,460.0 \\
\text { (3) }\end{array}$ & $\begin{array}{c}+2.4 \% \\
131\end{array}$ & $\begin{array}{c}54,800 \\
(19)\end{array}$ \\
\hline \multirow{7}{*}{ 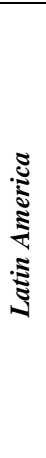 } & Argentina & $\begin{array}{c}927.4 \\
(26)\end{array}$ & $\begin{array}{c}-1.7 \% \\
211\end{array}$ & $\begin{array}{c}22,100 \\
(78)\end{array}$ \\
\hline & Brazil & $\begin{array}{c}3,073.0 \\
(8)\end{array}$ & $\begin{array}{c}+0.3 \% \\
198\end{array}$ & $\begin{array}{c}15,200 \\
(101)\end{array}$ \\
\hline & Chile & $\begin{array}{c}410.3 \\
(44)\end{array}$ & $\begin{array}{c}+2.0 \% \\
151\end{array}$ & $\begin{array}{c}23,200 \\
(76)\end{array}$ \\
\hline & Columbia & $\begin{array}{c}642.7 \\
(32)\end{array}$ & $\begin{array}{c}+5.0 \% \\
54\end{array}$ & $\begin{array}{c}13,500 \\
(111)\end{array}$ \\
\hline & Costa Rica & $\begin{array}{l}71.2 \\
(93)\end{array}$ & $\begin{array}{c}+3.6 \% \\
83\end{array}$ & $\begin{array}{c}14,900 \\
(104)\end{array}$ \\
\hline & Peru & $\begin{array}{c}376.7 \\
(48)\end{array}$ & $\begin{array}{c}+3.6 \% \\
80\end{array}$ & $\begin{array}{c}12,000 \\
(119)\end{array}$ \\
\hline & Venezuela & $\begin{array}{c}545.7 \\
(35)\end{array}$ & $\begin{array}{c}-3.0 \% \\
213\end{array}$ & $\begin{array}{c}17,900 \\
(88)\end{array}$ \\
\hline
\end{tabular}

Resources:

1 https://www.cia.gov/library/publications/resources/theworld-factbook/rankorder/2001rank.html

2 https://www.cia.gov/library/publications/resources/theworld-factbook/rankorder/2003rank.html

3 https://www.cia.gov/library/publications/resources/theworld-factbook/rankorder/2004rank.html

\section{Total Gross Domestic Product}

The U.S. had the highest total gross domestic product among the NAFTA countries at $\$ 17,460.0 \mathrm{~B}$ (third highest in the world) and Canada had the lowest at \$1,579.0B (??). Among the Latin American countries, Brazil had the highest GDP at $\$ 3,073.0 \mathrm{~B}$ (eighth in the world) and Costa Rica had the smallest at $\$ 71.2 \mathrm{~B}\left(93^{\text {rd }}\right.$ highest).

\section{GDP Growth Rate}

All three NAFTA countries were relatively close in annual GDP real growth rate at approximately $+2.4 \%$. They were also relatively close in world rank (ranging between $131^{\text {st }}$ and $137^{\text {th }}$ highest). Among the Latin American countries, Columbia had the highest GDP growth rate at $5.0 \%\left(54^{\text {th }}\right.$ highest in the world) and Venezuela had the lowest at $-3.0 \%\left(213^{\text {th }}\right.$ highest $)$.

\section{GDP Per Capita}

The U.S. had the highest annual GDP per capita among the NAFTA countries at $\$ 54,800\left(19^{\text {th }}\right.$ highest in the world) and Mexico had the lowest at

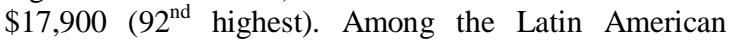
countries, Chile had the highest GDP per capita at $\$ 23,200$ ( $\left(76^{\text {th }}\right.$ highest in the world) and Peru had the smallest at $\$ 12,000\left(119^{\text {th }}\right.$ highest $)$.

Table 3 includes total exports (2014 estimates, in U.S. dollars using the free on board basis and calculated on an exchange rate basis), major export partners (as a percentage of country's total exports), total imports (2014 estimates, in U.S. dollars using the cost, insurance, and freight basis or free on board basis), and major export partners (as a percentage of country's total exports). We have also included a corresponding world rank for each of these indicators.

\section{Total Exports}

The U.S. had the highest total exports among the NAFTA countries at $\$ 1,610.0 \mathrm{~B}$ (third highest in the world) and Mexico had the lowest at $\$ 406.4 \mathrm{~B}\left(15^{\text {th }}\right.$ highest). Among the Latin American countries, Brazil had the highest total exports at $\$ 242.7 \mathrm{~B}\left(24^{\text {th }}\right.$ highest in the world) and Costa Rica had the smallest at $\$ 11.8 \mathrm{~B}$ ( $91^{\text {st }}$ highest).

\section{Major Export Partners}

The vast majority of exports from both Canada and Mexico went to the U.S. (76.8\% and 80.3\%, respectively). The largest percentage of U.S. exports went to Canada (19.3\%) and Mexico (14.8\%). The highest percentage of exports from Argentina went to Brazil (20.3\%). Similarly, Brazil exported the most to China (18.0\%), Chile to China (24.6\%), Columbia to the U.S. (26.4), Costa Rica to the U.S. (47.4\%), Peru to China (18.3\%), and Venezuela to the U.S. (28.8\%).

\section{Total Imports}

The U.S. had the highest total imports among the NAFTA countries at $\$ 2,334.0 \mathrm{~B}$ (highest in the world) and Mexico had the lowest at $\$ 407.1 \mathrm{~B}\left(14^{\text {th }}\right.$ highest). Among the Latin American countries, Brazil had the highest total exports at $\$ 241.9 \mathrm{~B}\left(23^{\text {rd }}\right.$ highest in the world) and Costa Rica had the smallest at $\$ 17.9 \mathrm{~B}\left(80^{\text {th }}\right.$ highest). 
Table 3: 2014 Exports and Imports by Country

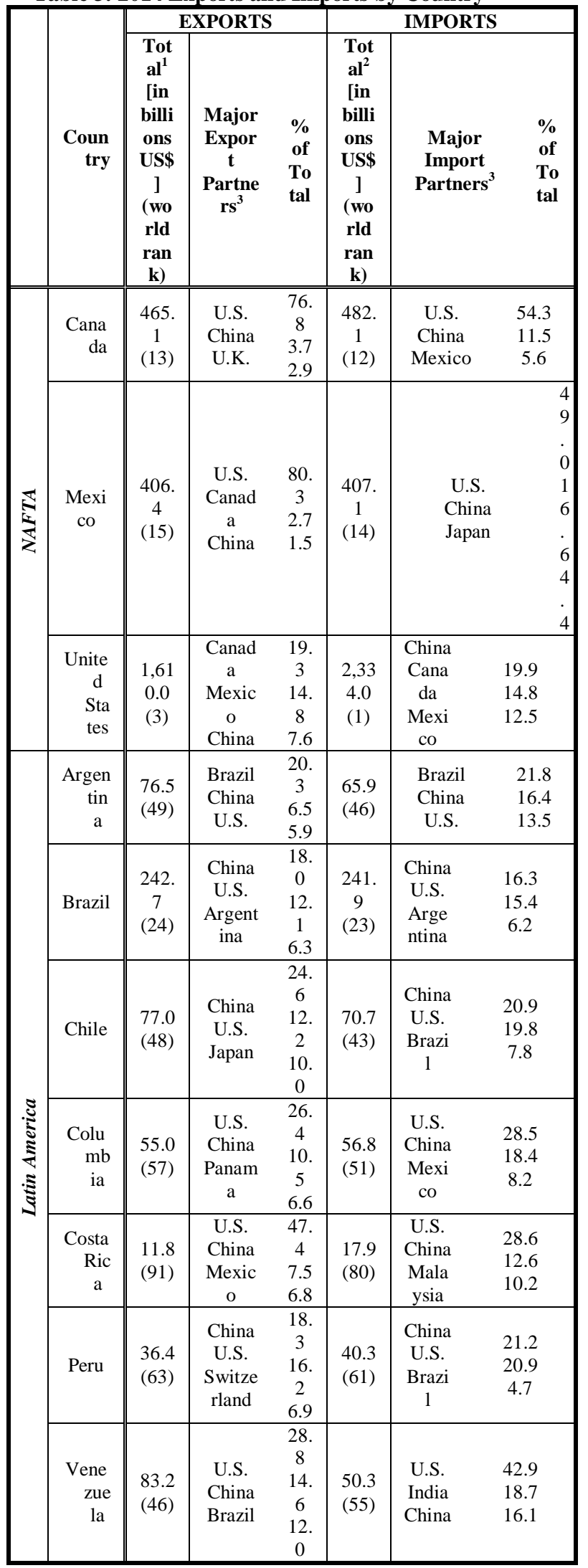

Resources:

1 https://www.cia.gov/library/publications/resources/theworld-factbook/rankorder/2078rank.html
2 https://www.cia.gov/library/publications/resources/theworld-factbook/rankorder/2087rank.html

3 http://comtrade.un.org/data

\section{Major Import Partners}

The largest proportion of imports to both Canada and Mexico came from the U.S. (54.3\% and $49.0 \%$, respectively). The largest percentage of imports to the U.S. came from China (19.9\%). The highest percentage of imports to Argentina came from Brazil (21.8\%). Similarly, Brazil imported the most from China (16.3\%), Chile from China (20.9\%), Columbia from the U.S. (28.5), Costa Rica from the U.S. (28.6\%), Peru from China (21.2\%), and Venezuela from the U.S. (42.9\%).

Figure 1 displays a comparison of 2014 imports and exports among the included countries.

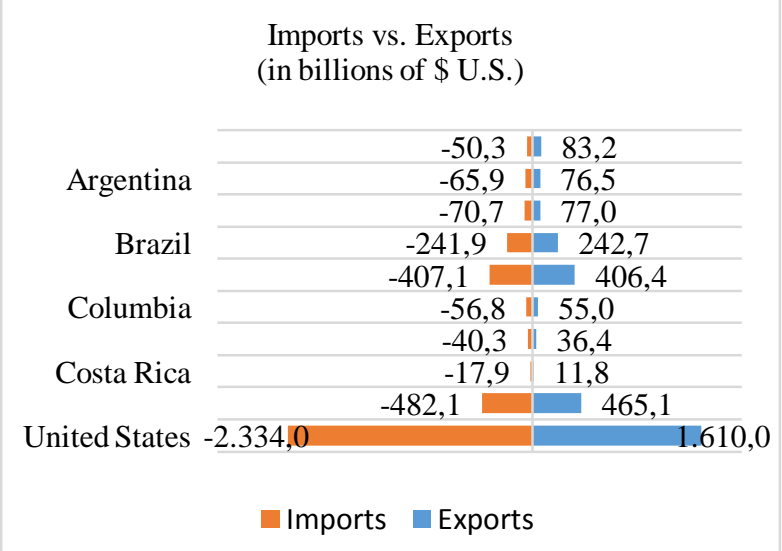

\section{Figure 1. Imports vs. Exports Balance of Trade}

The balance of trade for each of the NAFTA countries was negative, ranging from $-724.0 \mathrm{~B}$ for the U.S. to $-0.7 \mathrm{~B}$ for Mexico. Among the Latin American countries, Venezuela had the highest balance of trade at $+\$ 32.9 \mathrm{~B}$ and Costa Rica had the lowest at $-\$ 6.2 \mathrm{~B}$. Table 4 presents a listing of all included countries ranked by decreasing 2014 balance of trade in billions of U.S. dollars.

Table 4: 2014 Balance of Trades by Decreasing Amount

\begin{tabular}{|c||c|}
\hline Country & $\begin{array}{c}\text { Balance } \\
\text { [in billions US\$] }\end{array}$ \\
\hline \hline Venezuela & 32.9 \\
\hline Argentina & 10.6 \\
\hline Chile & 6.3 \\
\hline Brazil & 0.8 \\
\hline Mexico & -0.7 \\
\hline Columbia & -1.8 \\
\hline Peru & -3.8 \\
\hline Costa Rica & -6.2 \\
\hline Canada & -17.0 \\
\hline United States & -724.0 \\
\hline
\end{tabular}


Figures 2 and 3 depict the three largest export partners (outflowing arrows) of each NAFTA and Latin American country, respectively, based on percent of the exporting country's total exports. Circles are in proportion to total of each country's total exports (shown below country name).

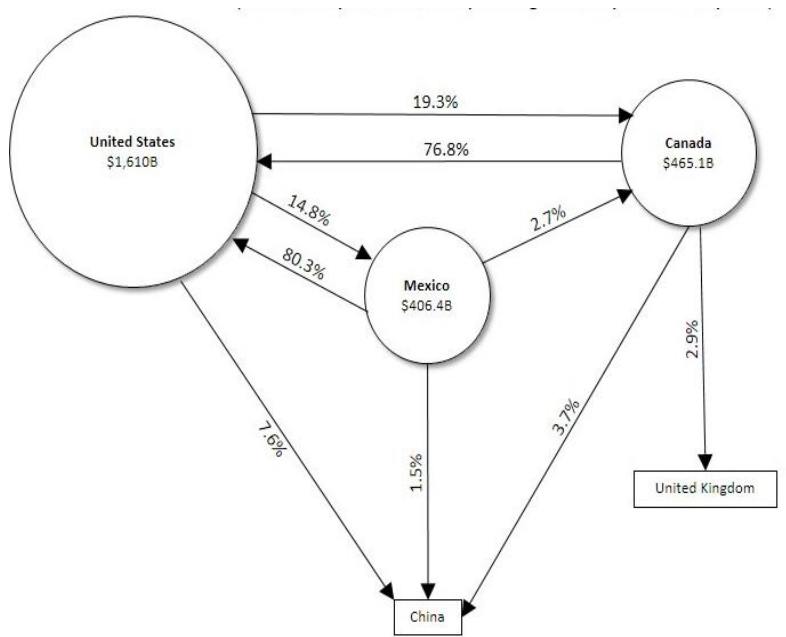

Figure 2. Largest Export Partners for NAFTA Countries

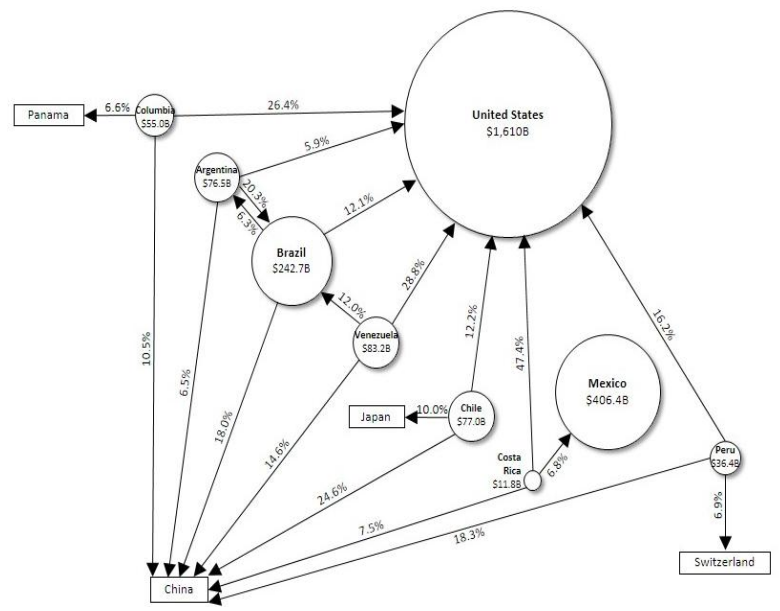

Figure 3. Largest Export Partners for Latin American Countries

Figures 4 and 5 depict the three largest import partners (inflowing arrows) of each NAFTA and Latin American country, respectively, based on percent of the importing country's total imports. Circles are in proportion to total of each country's total imports (shown below country name).

\section{Methodology and Data}

Multiple Discriminant Analysis - MDA (see, e.g., Altman, 1968; Stevens, 1973; Belkaoui, 1978) and Multivariate Analysis of Variance - MANOVA (see, e.g., Hutchinson et al., 1988; Meric et al., 1991) are the two multivariate techniques most commonly used in previous studies to compare the financial characteristics of different groups of firms. In this study, we use the
MANOVA technique to compare the financial characteristics of NAFTA and Latin American manufacturing firms. Detailed information about the MANOVA technique can be found in Marascuilo and Levin (1983) and Johnson and Wichern (2007).

Financial ratios are generally used in empirical studies to compare the financial characteristics of different groups of firms. The financial ratio data used in this study were obtained from the 'Research Insight/Global Vintage' database in October 2015. Manufacturing industries with SIC codes between 20003999 are included in the study. Our research sample consists of 885 NAFTA and 849 Latin American manufacturing firms. We use the financial ratios presented in Table 5 as measures of firm financial characteristics in the comparisons.

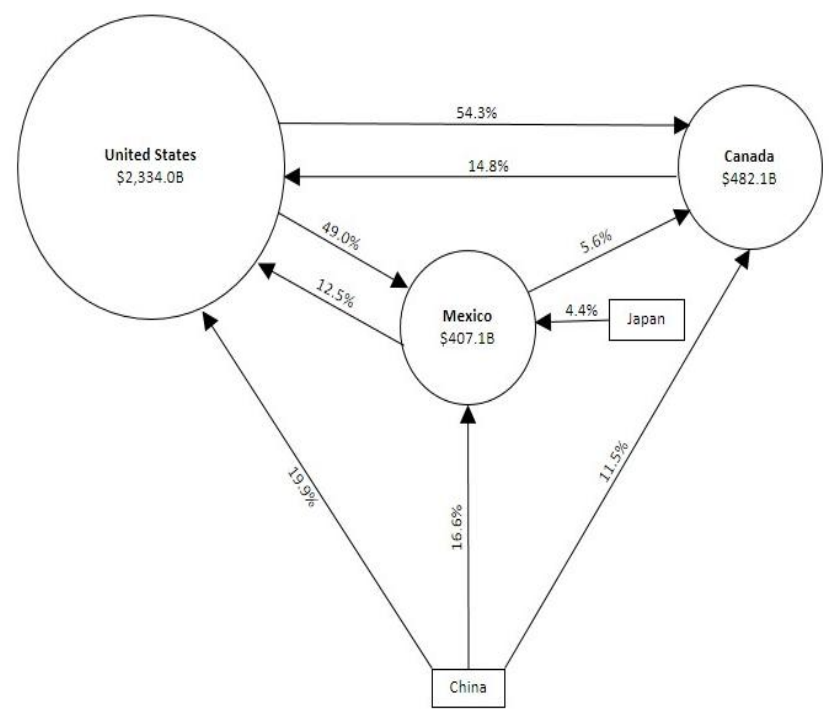

Figure 4. Largest Import Partners for NAFTA

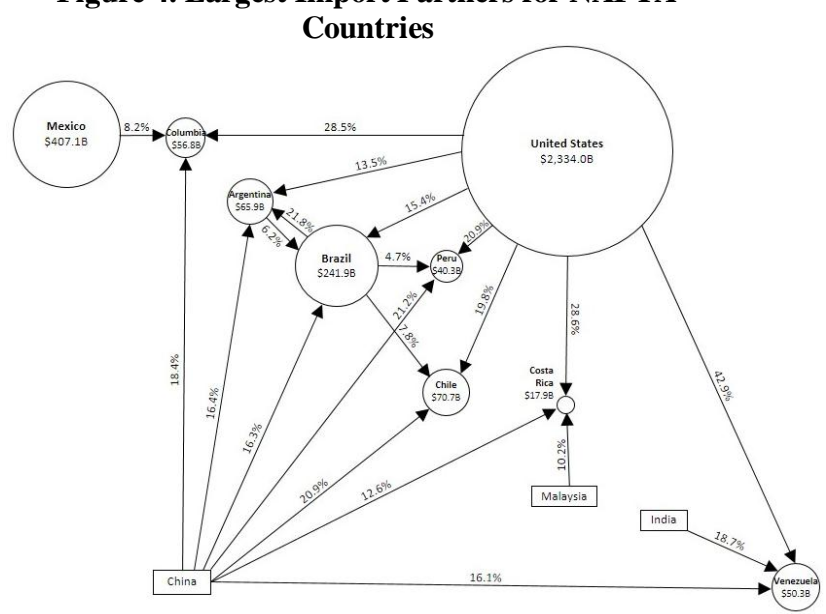

Figure 5. Largest Import Partners for Latin American Countries 
Table 5: Financial Ratios Used in the Study as Measures of Firm Financial Characteristics
Financial Ratio Definition

Liquidity

Current Ratio

Quick (Acid-Test) Ratio

Average Collection Period

Inventory Turnover

Fixed Assets Turnover

Total Assets Turnover

Assets

Financial Leverage

Equity Ratio

Profitability

Net Profit Margin

Sales

Return on Assets

Return on Equity

Growth

Sales Growth Rate

Total Assets Growth Rate

Net Income /
Common Equity

/ Total Liabilities

Financial Ratio

Current Assets /

Current

Liabilities

(Current Assets -

Inventories) /

Current

Liabilities

Sales / (Accounts

Receivable / 365)

Sales /

Inventories

Sales / Net Fixed

Assets

Sales / Total

Net Income /

Total Assets

Net Income /

Common Equity

Average for the Last Three Years Average for the Last Three Years

\section{MANOVA Method}

Multivariate analysis of variance (MANOVA) is the extension of univariate techniques for discovering differences between group means. When two groups are involved, a $t$ test can be used; when three or more groups are involved ANOVA (analysis of variance) can be used for the purpose. The terms "univariate" and "multivariate" refer to the number of dependent variables tested. The null hypothesis tested in the $t$ test and ANOVA is the equality of means of a single dependent variable across groups. In other words, ANOVA tests if the differences among the group means of a single dependent variable are statistically significant, or likely to have happened by chance. In MANOVA, the null hypothesis tested is the equality of vectors of means of multiple dependent variables across groups. In other words, MANOVA tests if the differences among the group means of a combination of dependent variables are significant, or likely to have occurred by chance. (Hair et al., 1998, Mertler and Vannatta. 2002) A MANOVA can also be considered as a way to test the hypothesis that one or more independent variables have an effect on two or more dependent variables. Consequently, a MANOVA has all the properties of an ANOVA, extended to multiple dependent variables. In addition to the similarities between ANOVA and MANOVA, the latter is statistically identical to discriminant function analysis. While MANOVA emphasizes the mean differences and the statistical significance of differences among groups, discriminant function analysis focuses on prediction of group membership and the dimensions on which groups differ. (Tabachnick and Fidell, 2001)

Although separate univariate ANOVA or $t$ tests can be used to accomplish what MANOVA does, this can lead to greatly inflated overall Type I error rate. Another problem with separate univariate analysis is that distributions of dependent variables might overlap such that a mean difference may not be found with ANOVA. However, when several dependent variables are considered in combination with each other, the groups may differ substantially and could result in a statistically significant difference among groups. (Mertler and Vannatta. 2002) Also, individual tests end up using less than the total information available about the dependent variables; this is because individual tests ignore the correlations among them. In case the dependent variables are correlated, MANOVA may detect combined differences not discovered in univariate tests. Consequently, MANOVA will be more powerful than the separate univariate tests. (Hair et al. 1998)

Just like any other statistical method, MANOVA has some limitations. The first of these is the attribution of causality to the relationship between independent and dependent variables; the statistical test does not confirm causality. Care must be exercised in choosing independent variables and their levels, and ideally dependent variables must be uncorrelated with each other. In addition to these theoretical issues, practical issues concerning the statistical procedures must be considered. One of these is related to sample size; it is necessary to have more cases than dependent variables in every cell. If a cell has more dependent variables than cases, the assumption of homogeneity becomes untestable. Also, the power of the test is reduced if the number of dependent variables is more than the cases due to the reduced degrees of freedom for error. (Tabachnick and Fidell, 2001) A serious limitation of MANOVA, as well as ANOVA, is the sensitivity to outliers. An outlier can produce either a Type I or Type II error, without providing any clues as to which one has occurred. (Tabachnick and Fidell, 2001) MANOVA assumes linear relationship between each pair of dependent variables, as well as all pairs of covariates and all dependent variable covariate pairs in each cell. Deviations from this assumption reduce the power of the statistical tests, because "(1) the linear combinations of dependent variables do not maximize the separation of groups for the independent variables, and (2) covariates do not maximize adjustment for error." (For further discussion of limitations of MANOVA see Tabachnick and Fidell, 2001, and Hair et al. 1998. Also, see Hair et al. 1998. For a detailed procedure of application of MANOVA) 


\section{Empirical Findings}

Our MANOVA test results are presented in Table 6. The multivariate $\mathrm{F}$ value test statistic (38.1) in the table indicates that the overall financial characteristics of NAFTA and Latin American manufacturing firms are significantly different at the 1percent level.

Table 6: MANOVA Statistics

\begin{tabular}{|c|c|c|c|c|}
\hline $\begin{array}{c}\text { Financial } \\
\text { Ratios }\end{array}$ & \multicolumn{2}{|c|}{$\frac{\text { Means and Standard }}{\text { Deviations } \dagger}$} & $\frac{\text { Univariate }}{\underline{\text { Statistics }}}$ & $\begin{array}{l}\frac{\text { te }}{s} \\
\underline{P}-\end{array}$ \\
\hline \multicolumn{5}{|c|}{ Liquidity Ratios } \\
\hline $\begin{array}{c}\text { Quick } \\
\text { (Acid- } \\
\text { Test) } \\
\text { Ratio }\end{array}$ & $\begin{array}{c}2.90 \\
(1.81) \\
1.86 \\
(1.52)\end{array}$ & $\begin{array}{c}2.68 \\
(2.99) \\
1.97 \\
(2.64)\end{array}$ & $3.46^{*}$ & 0.28 \\
\hline
\end{tabular}

Asset Management Ratios

\begin{tabular}{|c|c|c|c|c|}
\hline \multirow{2}{*}{\multicolumn{5}{|c|}{$\begin{array}{l}\text { Average } \\
\text { Collection }\end{array}$}} \\
\hline & & & & \\
\hline & \multirow{5}{*}{$\begin{array}{c}53.55 \\
(23.63) \\
5.57 \\
(4.32) \\
6.94 \\
(5.36) \\
1.04 \\
(0.51)\end{array}$} & 97.01 & & \\
\hline Inventory & & (81.18) & $33.07 * * *$ & 0.00 \\
\hline Turnover & & $\begin{array}{c}8.07 \\
(14.5)\end{array}$ & $24.05^{* * *}$ & 0.00 \\
\hline $\begin{array}{l}\text { Fixed } \\
\text { Assets }\end{array}$ & & $\begin{array}{c}7.57 \\
(18.43)\end{array}$ & 0.93 & 0.33 \\
\hline Turnover & & $\begin{array}{c}0.86 \\
(0.53)\end{array}$ & $4.99 * * *$ & 0.00 \\
\hline $\begin{array}{c}\text { Total } \\
\text { Assets }\end{array}$ & & & & \\
\hline Turnover & & & & \\
\hline
\end{tabular}

Financial Leverage

\begin{tabular}{c|cccc}
\hline Equity & \multicolumn{4}{l}{} \\
Ratio & 1.77 & 2.4 & & \\
& $(1.94)$ & $(3.66)$ & $20.01 * * *$ & 0.00 \\
\hline
\end{tabular}

Profitability Ratios

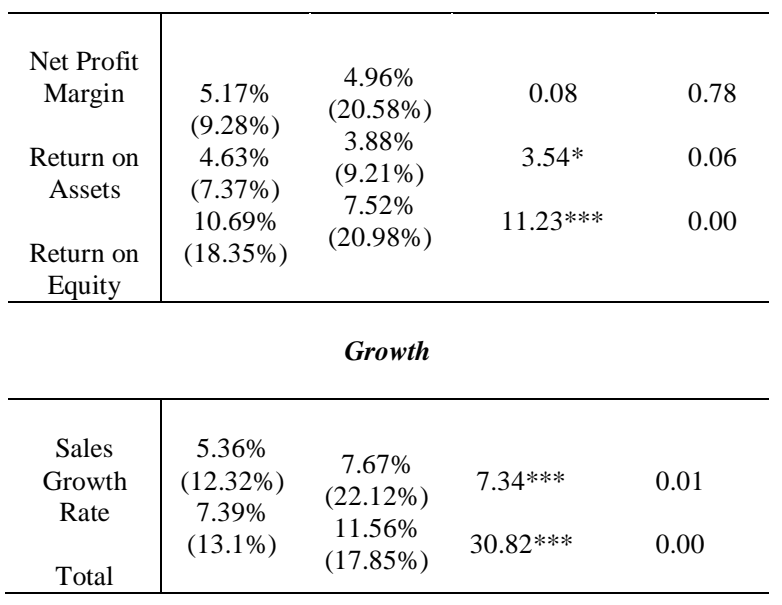

\begin{tabular}{|c|c|c|}
\hline $\begin{array}{c}\text { Assets } \\
\text { Growth } \\
\text { Rate }\end{array}$ & & \\
\hline Multiv & 38.1*** & 0.00 \\
\hline
\end{tabular}

The Multivariate Analysis of Variance (MANOVA) technique is used to compare the financial ratios of NAFTA and Latin American manufacturing firms. This table presents the mean ratios of NAFTA and Latin American manufacturing firms, the standard deviations of the ratios, and the univariate and multivariate test statistics.

$\dagger \quad$ The figures in parentheses are the standard deviations.

$* * *, * *, *$ indicate that the difference is significant at the 1-percent, 5-percent, and 10-percent levels, respectively. Liquidity

The univariate $\mathrm{F}$ value statistic (3.46) in Table 6 indicates that the mean current ratio of NAFTA manufacturing firms is significantly higher than the mean current ratio of Latin American manufacturing firms (2.9 vs. 2.68, respectively) at the 10-percent level. However, the mean quick (acid-test) ratios of NAFTA and Latin American manufacturing firms (1.86 vs. 1.97, respectively) are not significantly different. This result implies that NAFTA firms have a higher inventory level that makes the mean current ratio of NAFTA manufacturing firms to be significantly higher than that for Latin American manufacturing firms (i.e., the higher liquidity level of NAFTA manufacturing firms, as measured by the current ratio, is mainly due to NAFTA manufacturing firms carrying higher inventory levels compared with Latin American manufacturing firms).

\section{Asset Management}

The univariate $F$ value statistic (33.07) in Table 6 indicates that the average collection period is significantly shorter in NAFTA manufacturing firms (53.55 days) than in Latin American manufacturing firms (97.01 days) at the 1-percent level (i.e., NAFTA manufacturing firms are significantly more efficient in managing and collecting their accounts receivable compared with Latin American manufacturing firms).

The univariate $\mathrm{F}$ value statistic (24.05) indicates that inventory turnover is significantly higher in Latin American manufacturing firms (8.07) than in NAFTA manufacturing firms (5.57) at the 1-percent level. This indicates that Latin American manufacturing firms are more efficient in managing their inventories compared with NAFTA manufacturing firms. As we concluded when comparing the current and quick (acidtest) ratios above, this result also implies that NAFTA manufacturing firms tend to carry significantly higher levels of inventories compared to Latin American manufacturing firms.

The fixed assets turnover ratios of NAFTA and Latin American manufacturing firms are not significantly 
different. However, the univariate F value statistic (4.99) indicates that the mean total assets turnover ratio of NAFTA manufacturing firms is significantly higher compared with the mean total assets turnover ratio of Latin American manufacturing firms (1.04 vs. 0.86, respectively) at the 1-percent level. This implies a more efficient total assets management in NAFTA manufacturing firms than in Latin American manufacturing firms. NAFTA manufacturing firms are able to generate a larger amount of sales per dollar invested in total assets compared with Latin American manufacturing firms.

\section{Financial Leverage}

The univariate $F$ value statistic (20.01) in Table 6 indicates that the equity ratio (common equity/total liabilities) is significantly higher in Latin American manufacturing firms (2.4) than in NAFTA manufacturing firms (1.77) at the 1-percent level (i.e., Latin American manufacturing

firms use more equity financing and less debt financing compared with NAFTA manufacturing firms). This implies that Latin American manufacturing firms less financial risk compared with NAFTA manufacturing firms.

\section{Profitability}

Net profit margin is not significantly different in NAFTA and Latin American manufacturing firms. This implies no significant difference in product pricing and manufacturing costs of NAFTA and Latin American manufacturing firms. However, the univariate $F$ value statistic (3.54) in Table 6 indicates that the mean return on assets is significantly higher in NAFTA manufacturing firms than in Latin American manufacturing firms ( $4.63 \%$ vs. $3.88 \%$, respectively) at the 10-percent level. According to well-known DuPont system, this is mainly due to NAFTA firms being able to achieve a higher total assets turnover compared with Latin American manufacturing firms.

The univariate $\mathrm{F}$ value statistic (11.23) indicates that the mean return on equity is significantly higher in NAFTA manufacturing firms than in Latin American manufacturing firms $(10.69 \%$ vs. $7.52 \%$, respectively) at the 1-percent level. According to wellknown extended DuPont system, this result is due to NAFTA manufacturing firms having a higher total assets turnover and their using more financial leverage compared with Latin American manufacturing firms.

\section{Growth}

The univariate $F$ value statistic (7.34) in Table 6 indicates that the mean annual sales growth rate is significantly higher in Latin American manufacturing firms than in NAFTA manufacturing firms $(7.67 \%$ vs. $5.36 \%$, respectively) at the 1 -percent level. The second univariate $F$ value statistic (30.82) under growth indicates that the mean annual assets growth rate is also significantly higher in Latin American manufacturing firms than in NAFTA manufacturing firms $(11.56 \%$ vs. $7.39 \%$, respectively) at the 1-percent level. A comparison of the $F$ value statistics reveals that, the difference between the assets growth rates is more significant than the difference between the sales growth rates.

\section{Summary and Conclusions}

Comparing the financial characteristics of firms in different countries and regions has been a popular research topic in finance. MDA (Multiple Discriminant Analysis) and MANOVA (Multivariate Analysis of Variance) are the two popular statistical techniques used in comparisons. In this paper, we compare the financial characteristics of NAFTA and Latin American manufacturing firms with the MANOVA technique. Such a comparison has not been made in previous literature.

We use eleven financial ratios in the comparisons as measures of liquidity, asset management, indebtedness, profitability, and growth characteristics of the firms. The data of the study were obtained from the 'Research Insight/Global Vintage' database in October 2015. Our research sample includes 885 NAFTA and 849 Latin American manufacturing firms with SIC codes between 2000-3999.

Our multivariate test statistics indicate that the overall financial characteristics of NAFTA and Latin American manufacturing firms are significantly different. We find that NAFTA manufacturing firms are more profitable but they have greater financial risk compared with Latin American manufacturing firms. NAFTA manufacturing firms use more financial leverage to boast their earnings on equity.

Latin American manufacturing firms have more efficient inventory management. However, NAFTA manufacturing firms have more efficient accounts receivable management and total assets management. NAFTA manufacturing firms are able to earn significantly higher returns on their total assets investments mainly due to their achieving significantly higher total assets turnover rates. NAFTA manufacturing firms have more liquidity (i.e., NAFTA firms are better able to meet their maturing obligations) and they achieve significantly higher sales and total assets growth rates compared with Latin American manufacturing firms

\section{REFERENCES}

Altman, E. I. 1968. Financial Ratios, Discriminant Analysis, and the Prediction of Corporate Bankruptcy. Journal of Finance, 23 (4): 589-609.

Beaver, W. H. 1968. Alternative Financial Ratios as Predictors of Failure. Accounting Review, 43 (1): 113-122. 
Belkaoui, A. 1978. Financial Ratios as Predictors of Canadian Takeovers. Journal of Business Finance and Accounting, 5 (1): 93-108.

Dambolena, I. G., and S. J. Khoury. 1980. Ratio Stability and Corporate Failure. Journal of Finance, 35 (4): 1017-1026.

Deakin, E. B. 1972. A Discriminant Analysis of Predictors of Business failure. Journal of Accounting Research, 10 (1): $167-179$.

Edmister, R. O. 1972. An Empirical Test of Financial Ratio Analysis for Small Business Failure Prediction. Journal of Financial and Quantitative Analysis, 7 (2): 1477-1493.

Hair, J. F., Jr., R. E. Anderson, R. L. Tatham, and W. C. Black. 1998. Multivariate Data Analysis, 5th ed. Upper Saddle River, NJ: Prentice Hall.

Hutchinson, P., I. Meric, and G. Meric. 1988. The Financial Characteristics of Small Firms which Achieve Quotation on the UK Unlisted Securities Market. Journal of Business Finance and Accounting, 15 (1): 9-19.

Johnson, R. D., and D. W. Wichern. 2007. Applied Multivariate Statistical Analysis, 6th ed. Englewood Cliffs, NJ: Prentice Hall.

Kester, W. C. 1986. Capital and Ownership Structure: A Comparison of United States and Japanese Manufacturing Firms. Financial Management, 15 (1): 5-16.

Marascuilo, L. A., and J. R. Levin. 1983. Multivariate Statistics in the Social Sciences. Monterey, California: Brooks/Cole Publishing Company.

Meric, G., L. Kyj, C. Welch, and I. Meric. 2000. A Comparison of the Financial Characteristics of Japanese KieretsuAffiliated and Independent Firms. Multinational Business Review, 8 (2): 26-30.

Meric, G., S. S. Leveen, and I. Meric. 1991. The Financial Characteristics of Commercial Banks Involved in Interstate Acquisitions. Financial Review, 26 (1): 75-90.
Meric, G., and I. Meric. 1992. A Comparison of the Financial Characteristics of Listed and Unlisted Companies. MidWestern Journal of Business and Economics, 7 (1): 19-31.

Meric, I., and G. Meric. 1989. A Comparison of the Financial Characteristics of U.S. and Japanese Manufacturing Firms. Financial Management - FM Letters -, 18 (4): 9-10.

Meric, I., and G. Meric. 1994. A Comparison of the Financial Characteristics of United States and Japanese Manufacturing Firms. Global Finance Journal, 5 (1): 205-218.

Mertler, C. A., and R. A. Vannatta. 2002. Advanced and Multivariate Statistical Methods, 2nd ed. Los Angeles, CA: Pyrczak Publishing.

Moyer, R. C. 1977. Forecasting Financial Failure: A Re-examination. Financial Management, 6 (1): 11-17.

Rege, U. P. 1984. Accounting Ratios to Locate Take-over Targets. Journal of Business Finance and Accounting, 11 (3): 301311.

Stevens, D. L. 1973. Financial Characteristics of Merged Firms: A Multivariate Analysis. Journal of Financial and Quantitative Analysis, 8 (2): 149-158.

Tabachnick, B. G., and L. S. Fidell. 2001. Using Multivariate Statistics, 4th ed. Needham Heights, MA: Allyn and Bacon.

Wald, J. K. 1999. How Firm Characteristics Affect Capital Structure: An International Comparison. Journal of Financial Research, 22 (2): 161-187. 